\title{
Az Európai Unió és a tagállamok válasza a COVID-19 pandémiára - a szabad mozgás jogának közegészségügyi korlátozásai
}

\author{
Gyeney Laura ${ }^{*}$, Szabó Marcel ${ }^{1,2}$ \\ ${ }^{1}$ Pázmány Péter Katolikus Egyetem Jog- és Államtudományi Kar, Európajogi Tanszék, Budapest, Magyarország \\ ªlkotmánybíró, Alkotmánybíróság, Budapest, Magyarország
}

Beérkezett: 2021. július 12.; Elfogadva: 2021. augusztus 26.; Online megjelent: 2021. december 13.

\begin{abstract}
Összefoglalás
A szabad mozgás és tartózkodás joga az uniós polgárság alapintézményének egyik leglényegesebb eleme. A 2020-ban kirobbant koronavírus világjárvány következtében az Európai Unió tagállamai az Európai Unió történetében először kénytelenek voltak radikális, korábban nem alkalmazott eszközökkel korlátozni a szabad mozgás és tartózkodás jogát annak érdekében, hogy megakadályozzák a vírus terjedését. A tanulmány keretében a COVID-19 világjárvány miatt bevezetett korlátozások alapulvételével annak vizsgálatára kerül sor, hogy a szabad mozgás joga közegészségügyi okból történő korlátozása milyen sajátosságokkal bír más, az Európai Unió alapszerződéseiben ugyancsak nevesített kivételekhez (közrend, közbiztonság) képest. A tanulmány ugyancsak vizsgálja azt a kérdést, hogy az Európai Unió által kibocsátott digitális zöldútlevél (vakcinaigazolvány) a Sinopharm és Szputynik-V vakcinával beoltott uniós polgárok számára is biztosítandó-e az uniós jog rendelkezései alapján.
\end{abstract}

Kulcsszavak: COVID-19, szabad mozgás, vakcinaútlevél, közegészségügy, Európai Unió

\section{European Union and Member State Responses to the COVID-19 Pandemic - Restricting the Free Movement of EU citizens on Public Health Grounds}

\author{
Laura Gyeney ${ }^{1}$, Marcel Szabón ${ }^{1,2}$ \\ 'Pázmány Péter Catholic University Faculty of Law and Political Sciences, \\ Department of European Law, Budapest, Hungary \\ ${ }^{2}$ justice, Constitutional Court of Hungary, Budapest, Hungary
}

\begin{abstract}
Summary
The right of free movement of EU citizens is the cornerstone of Union citizenship. To control the spread of coronavirus (COVID-19) and to protect the health and well-being of all Europeans, Member States gave a surprisingly quick response, taking unilateral restrictive measures affecting the operation of the internal market in an unprecedented way. On the one hand they have implemented serious travel restrictions at internal borders of the EU. On the other hand, several States have coupled travel bans/restrictions with a temporary reintroduction of border controls at their borders with other Members of the Schengen Area. During the first wave of the pandemic, altogether 17 Schengen States sent notifications regarding the reintroduction of border controls, which is particularly disheartening given that the lifting of EU internal border controls in the Schengen Area is one of the integration's greatest achievements.

There is no doubt that the Member States' restrictions on free movement detailed in the paper are well-founded from the point of view of both public international law and European law. As to how they should be put into practice: that is another issue. Still, it is the preferential role of free movement as a part of integration that requires a deeper
\end{abstract}


examination of controversial measures to ascertain whether these are in compliance with EU legal principles. Among the elements to be reviewed are proportionality and the prohibition on discrimination.

It is beyond doubt that COVID-19 can definitely be regarded as a 'disease with epidemic potential' that can justify restrictions on free movement. However, the question arises whether Article 29 TFEU provides for the introduction of public health restrictions with general effect. In other words, does it allow for restrictions not based on individual assessment, as opposed to individual threats to public policy and public security? In answering the above question the paper puts a special emphasis on the delimitation of Member States' public health and public policy/ security justifications.

At the time of writing (June 2021) several Member States have already started to issue EU Covid-19 passports. The article also seeks answer to the question whether the Digital Green Certificate could (or, at least, should) be provided for Union citizens vaccinated with Sinopharm or Sputnik-V (vaccines approved by Hungary as a Member State, under European Union law).

Keywords: COVID-19, free movement, Digital Green Certificate, public health, European Union

\section{Bevezető gondolatok - a szabad mozgás jogának alapjai 1992 és 2020 márciusa között}

Az Európai Unió Mưködéséről szóló Szerződés (a továbbiakban: EUMSz.) 21. cikk (1) bekezdése (és ezzel lényegében azonosan az Európai Unió Alapjogi Chartájának 45. cikk (1) bekezdése) minden uniós polgár számára biztosítja a tagállamok területén való szabad mozgás és tartózkodás jogát. Az uniós polgárságra vonatkozó, a Maastrichti Szerződéssel bevezetett rendelkezések megszületése előtt a szabad mozgás és tartózkodás joga csak valamely gazdasági tevékenységgel összefüggésben, valamint három, gazdasági tevékenység folytatásától független, speciális irányelv hatálya alá tartozó személyi kör (diákok, keresőtevékenységgel felhagyó munkavállalók és önálló vállalkozók, valamint egyéb személyek) esetében volt biztosított (Osztovits 2011). Ezen, a szabad mozgás és tartózkodás jogát valamennyi uniós polgár számára biztosító rendelkezések a belső határellenőrzések eltörlését megvalósító schengeni acquis-val egyetemben közel 30 éven át megkérdőjelezhetetlen alapját képezték az Európai Unió egységes belső piacán belül az egyes uniós polgárokat megillető jogosultságoknak.

2020 tavaszán azonban új, az Európai Unió történetében mindeddig példa nélküli kihívással szembesültek az EU tagállamai: a Kínából induló COVID-19 vírus szinte pillanatok alatt elérte Európát. A tagállamok közül elsőként Olaszország jelentette a koronavírusos esetek számának egyre jelentősebb növekedését, majd 2020 márciusára a vírus lényegében az Európai Unió valamennyi tagállamában megjelent. Az Egészségügyi Világszervezet (WHO) fóigazgatója 2020. január 30-án nemzetközi horderejü közegészségügyi-járványügyi szükséghelyzetté, majd 2020. március 11 -én világjárvánnyá nyilvánította a COVID-19 okozta megbetegedéseket.

Jelen tanulmány a világjárványra adott, a szabad mozgás és tartózkodás jogát érintő európai uniós és tagállami válaszlépések áttekintésén és rendszerezésén keresztül arra keresi a választ, hogy mennyiben alkalmas az Európai Unió intézmény- és jogrendje egy, a COVID-19 jár- ványhoz hasonló rendkívüli válsághelyzet önálló kezelésére, illetve hogy milyen szerepet játszhatnak ebben maguk a tagállamok.

\section{A szabad mozgás jogára vonatkozó szabályozás elvi alapjai}

A szakirodalom a szabad mozgás uniós jogának három aspektusát különbözteti meg. A szabad mozgás joga mindenekelőtt a tagállami polgárnak egy az állampolgárságától eltérő tagállam területére történő belépését és tartózkodását szabályozó adminisztratív-rendészeti (idegenrendészeti) elő́rásokból áll. A szabályozás második szintjét a szabad mozgás célját képező védett, gazdasági vagy éppen nem gazdasági tevékenység folytatását a más tagállami polgár számára lehetôvé tevő vagy megkönnyítő szabályozás képezi (pl. munkavállalás, vállalkozás, családtagok beutazása, nyugdíjasok tartózkodása). A szabad mozgás jogának harmadik szintjét pedig az e jog gyakorlását megkönnyítő és elősegítő járulékos jogok biztosítása adja (pl. a helyi állampolgárokkal egyenlő bánásmód a szociális vagy oktatási kedvezmények esetén) (Blutman 2020). A COVID-19 világjárványra adott uniós, illetőleg tagállami szintú válaszlépések döntően a szabad mozgás jogára vonatkozó szabályozás legelső szintjét (azon belül is mindenekelőtt a más tagállamok területére történő belépés lehetőségeit) érintették, azonban értelemszerüen kihatottak annak második szintjére is.

A szabad mozgás és tartózkodás joga még „békeidőben" sem abszolút jog. A tagállamok a személyek szabad mozgását és tartózkodását korlátozó közegészségi, közrendi és közbiztonsági intézkedéseket vezethetnek be (így például az EUMSz. 45. cikk (3) bekezdése, 52. cikk (1) bekezdése, 62. cikke, vagy éppen a 2004/38/EK irányelv VI. fejezete alapján). Mint fent említettük, ezek a tagállami intézkedések elsősorban, de nem kizárólagosan a szabad mozgás jogának első, idegenrendészeti szintjét érintik. Az Európai Unió Bírósága gyakorlatában ugyanakkor nem csupán a közrendi, közbiztonsági és közegészségügyi korlátok kereteit, hanem magát a tagállami intézkedés fogalmát is meghatározta. Eszerint 
„intézkedésnek minősül minden olyan aktus, mely érinti a Szerződés cikkében meghatározott személyek azon jogát, hogy a tagállamokba a fogadó tagállam polgáraival azonos feltételek alapján belépjenek, és ott tartózkodjanak" (Bochereau ügy, 21. pont).

A közegészség védelme érdekében a szabad mozgás korlátozása csak a WHO által meghatározott járványos, karanténköteles betegségek, illetve olyan más, fertőző vagy ragályos parazitás betegségek esetében lehetséges, amelyekre vonatkozóan a tagállam állampolgárainak védelmét szolgáló rendelkezések vannak hatályban. A közegészség védelme érdekében meghozott korlátozásoknak is meg kell felelniük ugyanakkor az egyenló bánásmód és az arányosság jogelve követelményének, nem szolgálhatnak gazdasági célokat, tiszteletben kell tartaniuk az alapjogokat, illetve alkalmazásuk esetére megfelelő eljárási garanciáknak kell múködniük (Blutman 2020). Lényeges eltérés azonban a közegészségi, valamint a közrendi és közbiztonsági korlátozások között, hogy amíg az utóbbiak kizárólag az érintett személy magatartásán alapulhatnak, addig az uniós jog a közegészségi korlátozások esetében ilyen feltételt nem támaszt.

\section{Az egyes tagállami korlátozó intézkedések rendszerezése}

A COVID-19 világjárvány kirobbanását követően az EU tagállamai meglehetősen gyorsan elfogadták az elsô intézkedéseket. 2020 márciusának második felére már 16 tagállam állította vissza a légi és szárazföldi határain a határellenőrzést (a schengeni övezethez tartozó tagállamok közül elsőként Ausztria vezette ezt be az Olaszországgal közös határszakaszán), mellyel párhuzamosan pedig a tagállami beutazási és kiutazási tilalmak és korlátozások bevezetéséről is határoztak. Miközben ezen korlátozások és tilalmak tagállamonként más és más jogi formában és tartalommal léptek hatályba, az általánosságban kijelenthető, hogy a tagállamok (a vonatkozó nemzetközi jogi kötelezettségeiknek és saját alkotmányos követelményeiknek megfelelően) nem tiltották meg a saját állampolgáraik hazatérését.

Egyéni beutazási tilalom, illetőleg a beutazáshoz kapcsolódó szigorú karanténkötelezettség azon külföldi állampolgárokkal szemben került bevezetésre, akik a COVID-19 fertőzésre utaló tüneteket produkáltak, illetőleg a határátlépéskor elvégzett COVID-19 teszt pozitív eredményt mutatott. Magyarországon például a 2020. szeptember 1. napjától hatályos 408/2020. (VIII. 30.) Korm. rendelet $7 . \$(3)$ bekezdés a) pontja akként rendelkezett, hogy amennyiben a határátlépéskor elvégzett egészségügyi vizsgálat fertőzés gyanúját állapítja meg, a külföldi polgár Magyarország területére nem léptethető be.

Az egyes tagállamok kivételesen az egyedi tilalmon túlmutató, általános beutazási tilalom elrendeléséról is határoztak a járványügyi szempontból magas kockázatot jelentő államokból érkezőkkel szemben. Így például Magyarország a 41/2020. (III. 11.) Korm. rendelet 2. \$ (1) bekezdésével megtiltotta a járvány akkori európai gócpontjának számító Olaszországból érkező polgárok beutazását, oly módon, hogy Magyarország területére ebben az időszakban nem léphetett be Olaszország (valamint Kína, Dél-Korea és Irán) területéról érkező vasúti jármú, autóbusz, illetőleg - a leszállás nélküli áthaladás esetét kivéve - repülőgép. A magyar szabályozás, bár az elsők között került bevezetésre, azonban korántsem volt egyedi jellegú: így például Románia is hasonló intézkedést vezetett be Olaszországgal szemben, melynek következtében Magyarország egyenesen humanitárius folyosó nyitására kényszerült az Olaszországból az anyaországukba tömegesen, ámde egyénileg hazatérő román állampolgárok hazatérésének elősegítése érdekében.

A teljes beutazási tilalomtól megkülönböztethető az az esetkör, amikor az egyes tagállamok ugyan formálisan beutazási tilalmat vezetnek be, azonban a tilalom alóli kivételek nagy száma miatt valójában (a kérdéses intézkedést tartalma szerint értékelve) beutazási korlátozás elrendelésére kerül sor. A már említett, 2020. szeptember 1. napjától hatályos 408/2020. (VIII. 31.) Korm. rendelet 5. \$-a például akként rendelkezett, hogy „Nem magyar állampolgár személyforgalomban Magyarország területére - törvényben vagy kormányrendeletben meghatározott kivétellel - nem léphet be”. A megfogalmazás önmagában beutazási tilalomnak volna tekinthető, azonban a Korm. rendelet, valamint más jogszabályok számos kivételt biztosítottak a fószabály alól, tartalmában beutazási korlátozássá minősítve azt át. A Korm. rendelet 6 . $\$$ (2) bekezdése már önmagában is nyolc kivételt nevesített a beutazás tilalma alól, azonban a jogszabályi felsorolás utolsó, i) pontja tette mégis teljesen nyilvánvalóvá, hogy a Magyarország által elrendelt beutazási tilalom valójában „csak” beutazási korlátozás: a beutazás ugyanis a jogszabályban nevesített eseteken túlmenően is „egyéb méltányolható okból” engedélyezhető volt. Általában is kijelenthető, hogy a tagállamok a legtöbb esetben valójában (az intézkedés elnevezésétől függetlenül) beutazási korlátozások bevezetését határozták el, melyben „nyomós okból" lehetôvé tették a területükre történő belépést és tartózkodást.

A legtöbb tagállam jogrendszere ilyen nyomós oknak minősítette az üzleti-gazdasági célú tevékenységet, azonban még ebben a látszólag teljesen nyilvánvaló kivételszabály esetében sem figyelhető meg az Európai Unió tagállamai között a teljes azonosság. Így például Dánia hosszú időn keresztül még üzleti-gazdasági célból sem engedélyezte a beutazást a nem saját állampolgárai számára, miközben Finnország a COVID-19 korábbi hullámai alatt mindvégig lehetővé tette a munkavállalási és üzleti célú beutazást azok számára, akik a társadalom múködése és az ellátásbiztonság szempontjából nélkülözhetetlen tevékenységet folytatnak. Hasonló intézkedést vezetett be 2021 tavaszán Németország is, amely a brit variáns felbukkanását követően az Ausztriával, ille- 
tőleg Csehországgal közös határszakaszán csak az alapvető fontosságú munkakörben dolgozó külföldi polgárok beutazását engedélyezte (Gyeney 2021).

Áttekintve az egyes EU-tagállamok gyakorlatát, megállapítható, hogy a legtöbb tagállam a beutazási tilalom, illetóleg korlátozás alóli kivételek körébe sorolta a hallgatói jogviszony alapján fennálló tanulmányi kötelezettségek teljesítését, a nyomós családi és magánéleti okokat (mint például a házasságkötést vagy éppen temetést), vagy éppen az egészségügyi ellátások igénybevételét.

Tekintettel arra, hogy a szabad mozgás és tartózkodás jogának korlátozása kifejezetten közegészségügyi okból történt, ezért még azokban a kivételes esetekben is, amikor az egyes tagállamok lehetővé tették a területükre történő beutazást, lényeges kérdés volt annak igazolása, hogy a beutazó személy egyébként nem jelent közegészségügyi kockázatot a fogadó tagállam számára. E körben a tagállami szabályozások értékelése szempontjából pedig annak is jelentősége van, hogy a beutazni kívánó személy járványügyi szempontból magas vagy alacsony kockázatú országból, illetőleg régióból érkezett-e. Különösen a COVID-19 járvány kezdeti időszakában jelentett komoly bizonytalansági tényezőt, hogy egységes uniós szintű kockázatértékelés hiányában az egyes tagállamok eltérően határozták meg az általuk kockázatosnak tartott tagállamokat, illetóleg régiókat, ekként adott esetben egy több tagállamot érintő utazás esetén (például ha valaki Lengyelországból kívánt Magyarországra utazni) eltéró szabályokkal szembesült az egyes tagállami határokon.

A legtöbb tagállam általában legfeljebb 72 órával az érkezés előtt elvégzett negatív (PCR vagy antigén) COVID-teszthez kötötte a beutazást a magas kockázatú régiókból érkezők számára. Ez a tagállamok nagy részében kiegészült a beutazást követő karantén elrendelésével, mindenekelőtt házi karantén formájában. A kötelező karantén időtartamát a tagállamok a járvány első hullámában jellemzően 14 napban, a második, illetőleg a harmadik hullámban már csak 10 napban határozták meg. A legtöbb tagállamban a karantén kiváltható volt legalább egy, de jellemzően két negatív teszttel (kéttesztes stratégia), ennek feltételei azonban ugyancsak eltértek egymástól. A fentieken túlmenően, számos tagállam vezette be az ún. passenger locator form kitöltésének kötelezettségét is a beutazók részére, elsősorban a járványügyi szempontból magas kockázatú régiókból történó beutazások esetén, melyben az érintetteknek meg kellett jelölniük azon területeket, ahol a beutazást megelőző két hétben jártak.

A teljesség kedvéért érdemes megemlítenünk, hogy az Európai Unió tagállamai nem csupán a tagállamok közötti, hanem a tagállamokon belül szabad mozgás jogát is korlátozták a COVID-19 veszélyhelyzet időszakában (lockdown). A lockdown magában foglal minden, a tagállamon belüli mozgással kapcsolatos korlátozást, ideértve az általános kijárási tilalmat éppúgy, mint az államon belüli regionális utazási korlátozásokat. Miközben ezeknek az intézkedéseknek jelentős szerepük volt a járvány elleni védekezésben, azok nemzetközi, illetőleg uniós jogi jelentősége csekély, és jelen tanulmány keretei között sem kerülnek értékelésre.

\section{Az utóbb megjelenő uniós jogi keretek}

Miközben a tagállamok az uniós jog általános szabályai alapján jogosultak voltak megalkotni a közegészségügyi kivételre hivatkozással a saját, a szabad mozgás jogának gyakorlását korlátozó szabályaikat, az egyes tagállamok gyakorlatai közötti jelentős eltérések (ideértve azt is, hogy pontosan kiket, pontosan mely tagállamokból, és pontosan milyen indokok alapján engedtek be a saját területükre) egyértelmúvé tették, hogy elkerülhetetlen a tagállami szabályozások bizonyos fokú koordinációja.

A Tanács már 2020. február 13-án következtetéseket fogadott el a COVID-19-ról, melyekben sürgette a tagállamokat, hogy közösen fellépve, a Bizottsággal együttmúködve, arányos és megfelelő módon alakítsanak ki szoros és fokozott koordinációt egymás között annak érdekében, hogy valamennyi intézkedés hatékonyságát biztosítani lehessen az Európai Unión belüli szabad mozgás megőrzése mellett (2020/C 57/04). Az Európai Unió állam- és kormányfői pedig 2020. március 10-én elvben elismerték, hogy a COVID-19 tekintetében közös európai megközelítésre van szükség - azonban, mint ahogy a már említett gyakorlat is mutatja, valójában az egyes tagállamok sokkal inkább hittek az egyéni, mint a közös, uniós szintű válságkezelés eredményességében. A Bizottság ezt követően számos közleményt, illetőleg iránymutatást adott ki annak érdekében, hogy előmozdítsa az egyes tagállami intézkedések koordinációját (csak a példa kedvéért: A Bizottság közleménye COVID-19 A munkavállalók szabad mozgáshoz való jogának gyakorlására vonatkozó bizottsági iránymutatások, 2020/C 102 I/03, vagy éppen a Bizottság közleménye az EU-ba irányuló, nem alapvetően szükséges utazásokra vonatkozó ideiglenes korlátozás alkalmazásának harmadik értékeléséről, COM(2020) 299 final). Ezen intézkedéseket összességében (mind kötelező erejük, mind pedig joghatásuk tekintetében) leginkább soft lawként értékelhetjük (Friedery 2020).

Látható, hogy az uniós jog utóbb megalkotásra került szabályai alapvetően elismerték a tagállamok jogát a közegészségügyi okból történő intézkedések meghozatalára, és elsősorban az egyes tagállami szabályozások harmonizációját, koordinációját célozták. Az Európai Unió szerepvállalásának ez a formája egyszerre fakadt abból a szükséges uniós hatáskörök hiányából és a rendkívül erôs tagállami szabályozási igényből, melynek oka egyaránt keresendő az egyes tagállami kormányok rendkívül gyors (számos esetben, például Magyarországon egyenesen rendkívüli jogrend bevezetésével járó) intézkedéseiben és az uniós döntéshozatal közismert lassúságában. 


\section{A tagállami korlátozó intézkedések értékelése az uniós jog fényében}

Láthattuk, hogy a COVID-19 válsághelyzettel kapcsolatosan elsősorban a tagállamok, és nem pedig maga az Európai Unió fogadta el a szükséges intézkedéseket. Tekintettel azonban arra, hogy a tagállami intézkedések közvetlenül is érintették a szabad mozgás és tartózkodás uniós jogból fakadó intézményét, ezért a tagállamok intézkedési jogköre nem volt korlátlan, hanem esetről esetre kell értékelnünk azok uniós joggal való összhangját.

\section{A határellenörzés visszaállitásával kapcsolatos tagállami intézkedések}

A Schengeni Határellenőrzési Kódex rendelkezései értelmében a tagállamok kivételesen, meghatározott időre visszaállíthatják a belső határellenőrzést az államhatáraikon, a közrendet vagy a belső biztonságot fenyegető komoly veszély esetén. A Kódex három esetben teszi lehetővé a határellenőrzés visszaállítását: a 25. cikk alapján előre látható események esetén, a 28. cikk alapján rendkívüli (előre nem látható) helyzetek esetén, míg a 29. cikk arra az esetre tartalmaz szabályokat, ha a belsó határellenőrzés nélküli térség általános múködése kerülne veszélybe a külső határellenőrzés végzése terén mutatkozó tartós és súlyos hiányosságok miatt. Érdemes összehasonlítanunk a 25 . és 28 . cikk alapján elrendelhető intézkedéseket.

1. táblázat |A Schengeni Határellenőrzési Kódex 25. és 28. cikke szerinti intézkedések összehasonlítása

\begin{tabular}{lll}
\hline 25. cikk & 28. cikk \\
\hline elrendelés oka & előre látható esemény & $\begin{array}{l}\text { előre nem látható } \\
\text { (rendkívüli) esemény }\end{array}$ \\
\hline & $\begin{array}{l}\text { a Bizottság és a többi } \\
\text { tagállam elózetes } \\
\text { értesítésével vezethetón } \\
\text { be }\end{array}$ & $\begin{array}{l}\text { az intézkedéssel } \\
\text { egyidejúleg kell a } \\
\text { Bizottságot és a többi } \\
\text { tagállamot értesíteni }\end{array}$ \\
\hline $\begin{array}{l}\text { elrendelés } \\
\text { időtartama }\end{array}$ & $\begin{array}{l}\text { legfeljebb 30 nap vagy } \\
\text { a veszély várható } \\
\text { időtartama }\end{array}$ & legfeljebb 10 nap \\
\hline meghosszabbítás & $\begin{array}{l}\text { legfeljebb 6 hónap, } \\
\text { kivételesen } \\
\text { (a 29. cikkel összhang- } \\
\text { ban) 2 év }\end{array}$ & \\
\hline
\end{tabular}

Forrás: a szerzők saját szerkesztése a Schengeni Határellenőrzési Kódex rendelkezései alapján

A COVID-19 járvány első európai hulláma idején öszszesen 17 schengeni állam döntött a határellenőrzések visszaállításáról. Az államok döntő többsége (14) a 28. cikk szerinti előre nem látható esemény klauzuláját hívta fel, azonban érdekes megemlíteni, hogy három tagállam már ebben az alapvető kérdésben is eltéró álláspontot képviselt: Finnország a járvány megfékezése eszközének, míg Dánia és Franciaország a már korábban bevezetett korlátozások újabb igazolási jogcímének tekintette a COVID-19 válsághelyzetet, ekként ez a három tagállam a 25. cikk szerint „elöre látható eseményként” hivatkozott a COVID-19 miatti korlátozások bevezetésére. Ugyancsak érdekes megemlíteni, hogy a 2 hónapos határidő leteltét követően már valamennyi tagállam „áttért" a 25. cikk alkalmazására annak érdekében, hogy hosszabb időn keresztül tarthassák fenn a bevezetett korlátozásokat.

Kevéssé közismert, de hat tagállam a COVID-19 válsághelyzet idején valójában nem új határellenőrzési korlátozást vezetett be, hanem csak a korábban elrendelt intézkedéseket hosszabbította meg. Ausztria, Dánia, Franciaország, Németország, a nem EU-tagállam (de a schengeni térséghez tartozó) Norvégia és Svédország a migrációs válság kirobbanása óta gyakorlatilag folyamatosan fenntartja a határellenőrzést, hol a terrorfenyegetettségre, hol pedig az illegális migránsok másodlagos mozgásából fakadó veszélyekre történő hivatkozással. Ez egyben annak is a bizonyítéka, hogy az egyes tagállamok az uniós jogvonatkozó rendelkezéseitől függetlenül továbbra is „kvázi szuverén döntésnek” tekintik a határellenőrzés visszaállíthatóságáról szóló döntéseiket (Thym-Bornemann 2020). Erdekes megemlíteni, hogy miközben ezen tagállamok gyakorlata legalábbis ellentétesnek tûnik az uniós jog betújével, tudomásunk szerint az Európai Bizottság mindössze egyetlen esetben határozott kötelezettségszegési eljárás megindításáról, és akkor sem a belső, hanem a külső határok védelmére vonatkozó elő́rísok Észtország általi megsértése miatt.

Megítélésünk szerint a bevezetett határellenőrzési intézkedések jogszerúsége (legalábbis azok kezdeti szakaszában) kétséget kizáróan igazolható volt. Annak ellenére igaz ez, hogy a Kódex a közegészségügyi kérdéseket nem említi sem a 25. cikk, sem pedig a 28. cikk alkalmazhatóságával összefüggésben. Ezt azonban maga a Bizottság is sokkal inkább szabályozási hiányosságként, mintsem az intézkedések bevezetése előtt álló abszolút tilalomként értékelte: „Rendkívül kritikus helyzetben a tagállamok a ragályos betegség jelentette kockázatra adott válaszként megállapíthatják a határellenőrzés viszszaállításának szüksségességét." (Az egészség védelmét, valamint az áruk és alapvető szolgáltatások rendelkezésre állását biztosító határigazgatási intézkedésekre vonatkozó iránymutatások, 2020/C $86 \mathrm{I} / 01,18$. pont.)

\section{A szabad mozgást korlátozó tagállami intézkedések}

A szabad mozgás irányelv (2004/38/EK irányelv) 29. cikke kifejezetten feljogosítja a tagállamokat, hogy a szabad mozgás és tartózkodás jogát korlátozó intézkedéseket fogadjanak el a WHO meghatározása szerint esetlegesen járványt okozó betegségek esetén, valamint más fertőző betegségek vagy ragályos parazitás megbetegedések esetén, ha az intézkedések a fogadó tagállam pol- 
gáraira vonatkozó védelmi rendelkezések hatálya alá tartoznak. Éppen ezért az egyes tagállamok szabad mozgást korlátozó intézkedései jogszerüségének előfeltétele volt a WHO azon 2020. márciusi döntése, mely a COVID-19 megbetegedéseket világjárványként ismerte el.

Ahogy azt már említettük, szemben a közrendre és közbiztonságra vonatkozó kivételek rendszerével, a közegészségügyi kivételeknek nem kell az egyén magatartásán alapulniuk. Ez azonban nem jelenti azt, hogy a tagállamokáltal közegészségügyi okból bevezetett kivételeknek ne kellene megfelelniük az uniós jogból fakadó elvi szempontoknak (egyenlő bánásmód, a korlátozás nem szolgál gazdasági célokat, arányosság, alapvető jogok tiszteletben tartása, megfelelő eljárási garanciák megléte). Azáltal azonban, hogy a közegészségügyi korlátozások nem az egyes tagállami polgárok személyes magatartására vezethetőek vissza, a megfelelő eljárási garanciák biztosításának kötelezettsége alapvetően eltér a közrendi és közbiztonsági kivételek körétől: e körben ugyanis az eljárási garanciák biztosítása leginkább csak abban a körben értelmezhető, hogy az uniós polgár valóban egy korlátozás alá tartozó tagállamból érkezve kíséreli-e meg a belépést, illetőleg, hogy valóban az egyes tagállamok által megjelölt kivételszabályok hatálya alá tartozik-e.

Álláspontunk szerint mindazon tagállami korlátozások, melyek objektív, a közegészségügyre (jelesül az egyes tagállamok fertőzöttségi rátájára) visszavezethető okból tesznek különbséget a beutazás engedélyezhetősége szempontjából az Európai Unió tagállamai között, a fenti feltételeknek megfelelőek, és ekként jogszerűnek tekinthetőek. Így például az ún. utazási buborékok (travel bubble) létrehozása sem feltétlenül ellentétes álláspontunk szerint az uniós jogból fakadó követelményekkel, azaz hogy egyes tagállamok úgy nyitották meg egymás felé a határaikat, hogy közben kifelé (más EUtagállamok irányába) fenntartották az utazási korlátozásokat. Elsőként Észtország, Lettország és Litvánia nyitott egymás között ilyen utazási buborékot. Az utazási buborékok jogszerú megteremtésének feltétele egyfelől az érintett tagállamok hasonló járványügyi mutatója, másfelől pedig (a diszkriminációmentesség követelményével összefüggésben) annak biztosítása, hogy valamennyi más, a buborékban részt vevő tagállammal hasonló helyzetben levő EU-tagállam esetében ugyanolyan feltételekkel válik lehetségessé a buborék egyes államai területére a beutazás. A Bizottság megfogalmazása szerint, „Amennyiben egy tagállam úgy dönt, hogy engedélyezi a területére vagy a területén belüli meghatározott régiókba és országrészekbe történő utazást, ezt megkülönböztetésmentes módon kell megtennie - vagyis lehetôvé kell tennie az odautazást az EU minden olyan régiójából vagy országából, ahol hasonló járványügyi helyzet áll fenn.” (A Bizottság közleménye, Út a szabad mozgás helyreállítására és a belső határellenőrzések megszüntetésére vonatkozó, fokozatos és összehangolt megközelítés kialakítása felé, 2020/C 169/03). E körben fontos előrelépést jelentett, hogy az Európai Betegség- megelőzési és Járványvédelmi Központ (ECDC) a tagállamok rendszeres adatközlései alapján színkódokkal segített az egyes tagállamok fertőzöttségi rátájának meghatározásában, illetőleg összehasonlításában.

A Tanács 2020. október 13-án elfogadott, 2020/1475 ajánlása utóbb teljesen egyértelmúvé tette, hogy a közegészségügyi indokból történő utazási korlátozások esetén az „egyenlő bánásmód” követelménye azt követeli meg, hogy az egyaránt biztonságos tagállamok esetében a szabad mozgás jogát a tagállamok nem korlátozhatják. Az ajánlás értelmében az ECDC zöld színkóddal jelöli azon tagállamokat, ahol a regisztrált COVID-19 esetek 14 napos öszszesített aránya 25-nél kevesebb, és az összes COVID-19 tesztból a pozitív teszteredmények aránya kevesebb mint 4\%. Az ajánlás 12. pontja értelmében pedig „A tagállamok nem korlátozhatják más tagállamoknak a $[\ldots]$ »zöld « besorolású területeire beutazó vagy onnan kiutazó személyek szabad mozgását.” (2020/1475 ajánlás).

A tanácsi ajánlás utóbb azt is egyértelmúvé tette, hogy az utazási korlátozások bevezetésekor, illetőleg fenntartásakor hogyan értelmezendő az arányosság követelménye: a tagállamoknak különbséget kell tenniük a „narancssárga” és a „piros” területek járványügyi helyzete között; a tagállamok figyelembe vehetnek további szempontokat (pl. kórházi ápolásra szorulók aránya, intenzív osztályra felvettek aránya, mortalitási ráta), melyeket az ECDC heti rendszerességgel közöl; a tagállamoknak figyelembe kell venniük a saját területükön fennálló járványügyi helyzetet; és végezetül, a tagállamoknak figyelembe kell venniük a tesztelési stratégiákat, és különös figyelmet kell fordítaniuk a magas tesztelési aránnyal rendelkező területek helyzetére.

$\mathrm{Az}$ egyes tagállami intézkedések értékelése során meggyőződésünk szerint azonban az egyes „jogon kívüli” (ha tetszik, politikai) szempontok sem hagyhatóak figyelmen kívül. A tagállamoknak a korlátozó intézkedéseik meghozatala során szükségképpen figyelembe kellett venniük az egészségügyi ellátórendszer kapacitásainak végességét, amely különösen az első és a második hullám idején egyértelmúen a szabad mozgás jogának szigorúbb korlátozását indokolta. Ezen intézkedéseket leginkább az elsősorban az egészséges környezethez való jog és a legmagasabb szintú testi és lelki egészséghez való jog körében értékelendő elővigyázatosság elve indokolhatta. A második, de különösen a harmadik hullám időszakában, amikor már meglehetősen pontosan lehetett ismerni a COVID-19 fertőzéssel kapcsolatos adatokat, a tagállamok szabályozása sokkal inkább a kevésbé szigorú megelőzés elve irányába mozdult el. Állításunkat alátámasztja, hogy a tagállamok a járvány második és harmadik hullámában a korábbiaknál jóval fertőzőbb brit vírusvariáns megjelenése ellenére sem vezettek be drasztikus utazási korlátozásokat, sőt a bevezetett korlátozások öszszességében enyhébbek (bár differenciáltabbak) voltak, mint az első hullám idején meghozott válaszlépések (Gyeney 2021). 


\section{A védőoltások elfogadása a közegészségügyi kivételek körében}

A szabad mozgás és tartózkodás joga közegészségügyi okból történő korlátozása tekintetében alapvető változást eredményezett a védőoltások egyre szélesebb körben történő elérhetővé válása. Az Európai Unió tagállamain belüli átoltottsági arány növekedése szükségképpen együtt járt a szabad mozgás jogát korlátozó intézkedések enyhébbé, illetőleg differenciáltabbá válásával, ugyanakkor egy új, korábban még nem tapasztalt problémát is felszínre hoztak.

A 2001/83/EK irányelv értelmében az Európai Unió területén a legtöbb gyógyszer (ideértve a koronavírus elleni védőoltásokat is) forgalomba hozatalának engedélyezése eredendően uniós hatáskör. Jelen tanulmány kéziratának 2021. júliusi lezárásáig az Európai Bizottság összesen négy COVID-19 oltóanyagra vonatkozóan adott ki feltételes forgalombahozatali engedélyt az Európai Gyógyszerügynökség kedvező értékelését követően: 2020. december 21-én a BioNTech/Pfizer, 2021. január 6-án a Moderna, 2021. január 29-én az AstraZeneca, 2021. március 11 -én pedig a Janssen (Johnson \& Johnson) védőoltása kapta meg a szükséges jóváhagyást. Az irányelv 5. cikk (2) bekezdése értelmében ugyanakkor „A tagállamok ideiglenesen engedélyezhetik valamely nem engedélyezett gyógyszer forgalmazását bármely olyan kórokozó, toxin, kémiai anyag vagy nukleáris sugárzás feltételezett vagy igazolt terjedése esetén, amely ártalmas lehet." Magyarország ezen rendelkezés alapulvételével 2021 februárjában előbb az orosz Szputnyik-V, majd a kínai Sinopharm védőoltásának ideiglenes engedélyét adta meg. A két, uniós forgalombahozatali engedéllyel nem rendelkező védőoltás helyzete ugyanakkor egymáshoz képest is eltérő: a WHO 2021 májusában a kínai Sinopharm védőoltás vészhelyzeti használatát jóváhagyta, amely ezzel bekerült a COVAX programba (COVID-19 Vaccines Global Access, a COVID-19 védőoltásokhoz való méltányos hozzáférést biztosító program), miközben az egyébként több mint 60 államban használt és az eddigi adatok szerint a kínai védőoltásnál is megbízhatóbbnak tûnő orosz Szputnyik-V a WHO jóváhagyásával nem rendelkezik.

A Magyarország által kiadott ideiglenes engedély uniós jogi megítélése akkor merült fel komolyan, amikor 2021. június 14-én elfogadásra került a 2021/953 rendelet az uniós digitális COVID-igazolvány, vagy közismerten a digitális zöldigazolvány bevezetéséról. A rendelet kizárólag az uniós forgalombahozatali engedéllyel rendelkező védőoltásokra vonatkozik, azonban az 5 . cikk (5) bekezdése értelmében a tagállamok elfogadhatják azokat az oltási igazolványokat is, amelyre valamely tagállam illetékes hatósága adott ideiglenes engedélyt, vagy pedig amely szerepel a WHO vészhelyzeti felhasználási engedélyt kapott oltóanyagokat tartalmazó listáján. Az egyenlő bánásmód követelményének megvalósulását célozza az az eloórás, hogy ha egy tagállam elfogad egy ilyen, tagállami ideiglenes engedéllyel vagy WHO jóváhagyással rendelkező védőoltás beadását tanúsító oltási igazolványt, akkor azonos feltételekkel el kell fogadniuk bármely más tagállam ugyanazon oltóanyagra vonatkozóan kiállított oltási igazolványát is. Miközben logikus, hogy egy, az Európai Unió által biztosított igazolvány csak az Európai Unió engedélyével rendelkező védőoltásokra terjed ki, felmerül a kérdés, hogy az idézett rendelkezés alapján hogyan kell az egyes tagállamoknak eljárniuk a tagállami ideiglenes engedéllyel rendelkező védőoltások esetén.

$\mathrm{Az}$ egyik lehetséges értelmezés szerint az Európai Unió többi tagállama a Szputnyik-V és Sinopharm oltást kapott uniós polgárokat teljesen azonos módon kezelheti a be nem oltott uniós polgárokkal, hiszen a digitális zöldigazolvány az Európai Unió által biztonságosnak és hatékonynak ítélt oltás beadását tanúsítja. A rendelet idézett 5. cikk (5) bekezdése ebben az értelemben is olvasható.

Álláspontunk szerint azonban a fenti értelmezés valójában az uniós joggal ellentétes eredményre vezetne. Maga az uniós jog teszi ugyanis lehetôvé, hogy a tagállamok kivételesen ideiglenes engedélyt adjanak egyes, uniós forgalombahozatali engedéllyel (még) nem rendelkező védőoltások számára. A tagállamok uniós jogon alapuló hatáskörét kérdőjelezné meg az az értelmezés, mely gyakorlatilag eltörölné az EUMSz. 21. cikk (2) bekezdéséből fakadó szabad mozgás jogát azon uniós polgárok vonatkozásában, akik az uniós jog rendelkezéseinek megfelelően engedélyezett védőoltással rendelkeznek. $\mathrm{Ez}$ az érvelés azonban megfordítva is igaz: a tagállamok kivételes, ideiglenes engedélyezési jogkörét tenné főszabállyá (vagy a főszabállyal egyenértékúvé) az az értelmezés, mely korlátozás nélkül, kötelezően elfogadandóvá tenné a valamely tagállam által ideiglenesen engedélyezett védőoltásokat. Megítélésünk szerint éppen ezért az arányosság elvének valójában egy köztes megoldás felel meg. Az uniós forgalombahozatali engedéllyel rendelkező védőoltások esetében az a megdönthetetlen vélelem érvényesül, hogy ezek a védőoltások hatékonyak. A semmilyen védőoltást nem kapott uniós polgárok esetében a tagállamok élhetnek azzal a megdönthetô vélelemmel, hogy a be nem oltott uniós polgárok COVID-19 vírushordozók és -fertőzők (fertőzöttség vélelme), ennek megfelelően teszteléssel, karanténkötelezettség előírásával vagy más módon velük szemben továbbra is hatályban tarthatják a közegészségügyi okokból bevezetett intézkedéseiket. A tagállami ideiglenes engedéllyel rendelkező védőoltással beoltott uniós polgárok helyzete pedig a két szélső kategória között alakul: esetükben érvényesülnie kell a hatékony oltás vélelmének, ez a vélelem azonban megdönthető: akár generálisan (annak igazolásával, hogy a kérdéses védőoltás valójában nem hatékony), akár individuálisan (annak igazolásával, hogy az adott védőoltást kapott uniós polgár esetében nem állt be a védettség, vagy akár COVID-19 fertőzöttnek is tekinthető). Mindez azonban csupán addig igaz, amíg a 
COVID-19 világjárvány tart: a járvány megszúnésével a járvány miatti közegészségügyi intézkedések is hatályukat kell hogy veszítsék.

\section{Záró gondolatok}

A COVID-19 világjárvány új, eddig soha nem tapasztalt kihívások elé állította az Európai Uniót. A koronavírus gyors terjedése és mutációja nem csupán világszinten, hanem az Európai Unió tagállamain belül is példátlanul szigorú intézkedések meghozatalát követelte meg. A szabad mozgás és tartózkodás magából az EUMSz. rendelkezéseiből fakadó jogának korlátozására az Európai Unióban hagyományosan az egyén magatartására visszavezethető közrendi vagy közbiztonsági okból került sor. Az elmúlt immáron közel másfél év számos tapasztalattal szolgált a szabad mozgás és tartózkodás joga közegészségügyi okból történő korlátozása gyakorlati alkalmazásával összefüggésben.

Egyértelmúvé vált, hogy az Európai Unió napjainkban is sokkal inkább szuverén államok nemzetközi szervezete, mintsem egy quasi föderális állam. Az Európai Unió nyújtotta jogi és gazdasági előnyök ugyanakkor még egy ilyen példátlan járványhelyzet idején sem mellőzhetőek: azáltal, hogy a 27 tagállam koordinálta-harmonizálta a bevezetett intézkedéseit (különösen a második hullám kezdetétől), hatékonyabbá vált a világjárvány Európai Unión belüli kezelése és különösen a világjárvány következményeinek enyhítése.

A világjárvány időszakában ugyancsak nyilvánvalóvá vált, hogy a közegészségügyi korlátozások rendszere tekintetében nem alkalmazhatóak (maradéktalanul) a közrendi és közbiztonsági korlátozásokkal összefüggésben kifejlesztett jogelvek. Különösen igaz ez az egyes tagállamok által önállóan (de az uniós jog keretei között) bevezetett járványügyi intézkedések uniós jogi megítélése tekintetében. Ezek sajátosságát nem csupán az jelenti, hogy a közegészségügyi korlátozások alapvetően nem az egyén magatartásán alapulnak, hanem sokkal inkább az, hogy nem csupán egy-egy tagállam, hanem az Európai Unió egészének koordinált fellépését igénylik, mely fellépés során szükségképpen számolni kell a tudományos bizonytalansággal is. Az egészségügyi kérdésekben teljesen elfogadott elővigyázatosság és megelőzés elvének megfelelő jogalkotás és jogalkalmazás pedig teljesen más mérce alkalmazását igényli, mint a „hagyományos”, közrendi és közbiztonsági korlátozások esetében. Meggyőződésünk szerint a COVID-19 világjárvány uniós jogi kezelése számos értékes tanulság levonását teszi lehetővé mind a jogalkotó, mind a jogalkalmazó számára - remélve persze, hogy ezen tanulságok gyakorlati alkalmazására a jövőben egyáltalán nem kerül majd sor.

\section{Irodalomjegyzék}

Blutman L. (2020) Az Európai Unió joga a gyakorlatban - a Brexit után. Budapest, HVG-ORAC

Friedery R. (2020) A szabad mozgás tagállamok közötti korlátozásának kérdései a COVID-19 idején. In: Gárdos-Orosz F. \& Lőrincz V. O. (szerk.) Jogi diagnózisok. A Covid-19-világjárvány hatásai a jogrendszerre. Budapest, L'Harmattan, pp. 261-272.

Gyeney, L. (2021) Editorial Comments: COVID-19 - EU Citizenship and the Right to Free Movement in a Public Health Crisis. Hungarian Yearbook of International Law and European Law, Vol. 9., pp. $5-22$.

Osztovits A. (szerk.) (2011) Az Európai Unióról és az Európai Unió Müködéséről szóló Szerződések Magyarázata II. Budapest, Complex

Thym, D. \& Bornemann, J. (2020) Schengen and Free Movement Law During the First Phase of the COVID-19 Pandemic: Of Symbolism, Law and Politics. European Papers, Vol. 5. Issue 3. pp. 1143-1170.

Az Európai Unió Múködéséról szóló Szerződés.

Az egészség védelmét, valamint az áruk és alapvető szolgáltatások rendelkezésre állását biztosító határigazgatási intézkedésekre vonatkozó iránymutatások, 2020/C 86 I/01.

A Bizottság közleménye - COVID-19, A munkavállalók szabad mozgáshoz való jogának gyakorlására vonatkozó bizottsági iránymutatások, 2020/C $102 \mathrm{I} / 03$.

A Bizottság közleménye, Az EU-ba irányuló, nem alapvetően szükséges utazásokra vonatkozó ideiglenes korlátozás alkalmazásának harmadik értékeléséról, COM(2020) 299 final.

A Bizottság közleménye, Út a szabad mozgás helyreállítására és a belső határellenőrzések megszüntetésére vonatkozó, fokozatos és összehangolt megközelítés kialakítása felé, 2020/C 169/03.

Az Európai Parlament és a Tanács 2001/83/EK irányelve (2001. november 6.) az emberi felhasználásra szánt gyógyszerek közösségi kódexéról

Az Európai Parlament és a Tanács 2004/38/EK irányelve (2004. április 29.) az Unió polgárainak és családtagjaiknak a tagállamok területén történő szabad mozgáshoz és tartózkodáshoz való jogáról, valamint az 1612/68/EGK rendelet módosításáról, továbbá a 64/221/EGK, a 68/360/EGK, a 72/194/EGK, a 73/148/EGK, a $75 / 34 /$ EGK, a $75 / 35 / E G K$, a $90 / 364 / E G K$, a $90 / 365 /$ EGK és a 93/96/EGK irányelv hatályon kívül helyezéséről.

Az Európai Parlament és a Tanács (EU) 2016/399 rendelete (2016. március 9.) a személyek határátlépésére irányadó szabályok uniós kódexéről (Schengeni Határellenőrzési Kódex).

Az Európai Parlament és a Tanács 2021. június 14-i (EU) 2021/953 rendelete a Covid19-világjárvány idején a szabad mozgás megkönynyítése érdekében az interoperábilis, Covid19-oltásra, tesztre és gyógyultságra vonatkozó igazolványok (uniós digitális Covidigazolvány) kiállításának, ellenőrzésének és elfogadásának keretéról.

A Tanács (EU) 2020/1475 ajánlása (2020. október 13.) a szabad mozgásnak a Covid19-világjárvány miatti korlátozására vonatkozó koordinált megközelítésról.

A Tanács következtetései a COVID-19-ről, 2020/C 57/04.

C-30/77. számú ügy, $\mathrm{R}$ kontra Pierre Bochereau, ECLI:EU:C: 1977:172.

41/2020. (III. 11.) Korm. rendelet az élet- és vagyonbiztonságot veszélyeztető tömeges megbetegedést okozó humánjárvány megelőzése, illetve következményeinek elhárítása, a magyar állampolgárok egészségének és életének megóvása érdekében elrendelt veszélyhelyzet során teendő intézkedésekről.

408/2020. (VIII. 31.) Korm. rendelet a járványügyi készültségi időszak utazási korlátozásairól.

A cikk a Creative Commons Attribution 4.0 International License (https://creativecommons.org/licenses/by/4.0/) feltételei szerint publikált Open Access közlemény, melynek szellemében a cikk bármilyen médiumban szabadon felhasználható, megosztható és újraközölhető, feltéve, hogy az eredeti szerző és a közlés helye, illetve a CC License linkje és az esetlegesen végrehajtott módosítások feltüntetésre kerülnek. (SID_1) 